\title{
Kemampuan Menulis Paragraf Eksposisi Oleh Siswa Kelas VII SMP Muhammadiyah 1 Medan
}

\author{
Oktavia Lestari P \\ Dosen FKIP Pendidikan Bahasa Indonesia \\ Universitas Muhammadiyah Sumatera Utara \\ oktavialestari@umsu.ac.id \\ Abstrak
}

Penelitian ini bertujuan untuk mengetahui kemampuan menulis paragraf eksposisi oleh siswa kelas VII SMP Muhammadiyah 1 Medan. Populasi penelitian adalah seluruh siswa kelas VII SMP Muhammadiyah 1 Medan yang berjumlah 40 orang (empat puluh) siswa. Metode yang digunakan adalah metode deskriptif, instrument penelitian yaitu tes kemampuan menulis paragraf eksposisi. Setelah menghitung dan mengolah data dari hasil penelitian yang dilakukan, diperoleh kesimpulan bahwa mengetahui kemampuan menulis paragraf eksposisi berdasarkan teknik klasifikasi oleh siswa kelas VII SMP Muhammadiyah 1 Medan berada pada tingkat cukup. Hal ini diketahui dari nilai rata- rata yang diperoleh siswa yaitu 5,90 yang dibulatkan menjadi 6 .

Kata kunci: Kemampuan Menulis, Paragraf, Paragraf Eksposisi

\section{A. PENDAHULUAN}

Keterampilan menulis merupakan keterampilan yang sangat penting dalam kehidupan, tidak hanya penting dalam kehidupan pendidikan, tetapi juga sangat penting dalam kehidupan masyarakat. Keterampilan menulis itu sangat penting karena merupakan salah satu keterampilan berbahasa yang harus dimiliki siswa. Dengan menulis siswa dapat mengungkapkan ekspresi, gagasan atau pendapat, pemikiran dan perasaaan yang dimiliki. Selain itu keterampilan menulis juga dapat mengembangkan daya pikir dan kreatifitas siswa dalam menulis.

Sebagai suatu keterampilan berbahasa, menulis merupakan kegiatan yang kompleks karena penulis dituntut untuk dapat menyusun isi tulisannya serta menuangkan dalam formulasi ragam bahasa 
tulis. Dibalik kerumitannya, menulis banyak mengandung manfaat bagi pengembangan mental, intelektual dan sosial seseorang. Menulis dapat meningkatkan kecerdasan, mengembangkan daya inisiatif, menumbuhkan keberanian, serta merangsang kemauan dan kemampuan mengumpulkan informasi.

Penulisan masalah dalam suatu penelitian adalah bagian yang sangat penting agar ruang lingkup dan batasan-batasan menjadi lebih jelas. Sesuai dengan pembatasan masalah serta pada tujuan penelitian ini, maka masalah dalam penelitian ini adalah "Bagaimanakah Kemampuan Menulis Paragraf Eksposisi Oleh Siswa Kelas VII SMP Muhammadiyah 1 Medan".

\section{B. KAJIAN TEORI}

\section{a. Pengertian Kemampuan}

Istilah kemampuan berasal dari kata "mampu" yang mendapatkan konfiks "kean” Menurut Poerdarminta (1984: 441) "Kemampuan ialah kesanggupan, kecakapan, atau kekuatan”. Selanjutnya, Semiawan (1999: 21) mengatakan "Kemampuan adalah daya untuk melakukan sesuatu tindakan sebagai hasil pembawaan dan latihan yang dapat dilakukan sekarang".

Oemar (1998: 1) mengatakan “Tiap individu mempunyai kemampuan sendiri, kemampuan itu bisa datang sendiri, pembawaan dari lahir dan faktor lingkungan. Apabila seseorang diasuh atau dididik terampil dalam suatu bidang atau lapangan, maka ia mampu melakukan kegiatannya dalam bidang tersebut".

Kemampuan identik dengan

keterampilan, kemampuan sangat menghendaki adanya tingkat perhatian, untuk mempertahankan perhatian yang tinggi diperlukan latihan secara terusmenerus. Dengan demikian seorang yang telah mengalami pelatihan yang terusmenerus dapat dikatakan kalau ia memiliki kemampuan dibidang yang ditekuni.

\section{b. Pengertian Menulis}

Menulis merupakan salah satu keterampilan berbahasa yang sangat dibutuhkan pada masa sekarang. Keterampilan menulis tidak mudah dimiliki dan memerlukan waktu yang lama untuk memperolehnya. Dengan menulis seseorang dapat mengekspresikan ide-ide atau gagasannya melalui bahasa tulis.

Tarigan (2005: 21) menyatakan "Menulis adalah menurunkan atau melukiskan lambang-lambang grafik yang menggambarkan suatu bahasa yang dipahami oleh seseorang sehingga orang lain dapat membaca lambang-lambang grafik 
tersebut kalau mereka memahami bahasa grafik itu”.

Widyamartaya (2002: 5) menyatakan bahwa mengarang atau menulis adalah kegiatan yang kompleks. Mengarang dapat kita pahami sebagai suatu rangkaian kegiatan seseorang mengungkakan gagasan dan menyampaikannya melalui bahasa tulis kepada pembaca untuk dipahami tepat seperti yang dimasudkan pengarang.

Tujuan pembelajaran menulis belum dicapai secara maksimal oleh siswa. Trimantara (2005: 1), penyebab tidak tercapainya tujuan pembelajaran menulis meliputi:

1. Rendahnya tingkat penguasaan kosakata sebagai akibat rendahnya minat baca.

2. Kurangnya penguasaan keterampilan mikrobahasa, seperti penggunaan tanda baca, kaidahkaidah penulisan, diksi, penyusunan kalimat dengan struktur yang benar sampai penyusunan karangan.

3. Kesulitan menemukan metode pembelajaran menulis yang sesuai dengan kondisi dan kemampuan siswa.
4. Ketiadaan atau keterbatasan media pembelajaran menulis yang efektif.

Marhijanto (1995: 140) menyatakan, tujuan menulis adalah:

1. Menyampaikan pokok pikiran atau gagasan kepada para pembaca.

2. Memberikan informasi tentang suatu masalah kepada pembaca.

3. Memberi hiburan dengan membaca.

Banyak keuntungan yang diperoleh dari kegiatan menulis diantaranya sebagai berikut:

1. Menulis dapat menggali kemampuan dan potensi diri, dengan menulis dapat mengetahui sampai dimana pengetahuannya tentang suatu topik, untuk mengembangkan topik penulis harus berpikir dan menggali pengetahuan dan pengalamannya.

2. Penulis dapat terlatih dalam berbagai pengungkapan gagasan atau ide. Dengan menulis penulis harus bernalar untuk menghubungkan berbagai gagasan. 
3. Penulis dapat lebih banyak menyerap serta menguasai informasi sehubungan dengan topik yang ditulis. Kegiatan menulis dapat memperluas wawasan penulis secara teoritis mengenai fakta-fakta yang berhubungan.

4. Penulis dapat berlatih dalam mengorganisasikan gagasan secara sistematis serta menggungkapkan secara tersurat .

5. Penulis akan dapat meninjau serta menulis gagasannya sendiri secara efektif.

6. Dengan menulis di atas kertas, penulis akan mudah memecahkan permasalahan yaitu dengan menganalisisnya secara tersurat dalam konteks yang lebih konkret.

7. Dengan menulis penulis terdorong untuk terus belajar secara aktif. Penulis menjadi penemu sekaligus pemecah masalah bukan sekedar menjadi penyerap informasi dari orang lain.

8. Dengan kegiatan menulis yang terencana, membiasakan penulis berfikir secara berbahasa secara tertib teratur.
Kedelapan kegiatan menulis sebagaimana dikemukakan di atas, bermanfaat dalam meningkatkan keterampilan siswa menulis. Hal ini disadari dengan kegiatan menulis maka akan semakin meningkatkan penguasaan kosa kata dan wawasan siswa dalam bidang keilmuan. Dengan menulis siswa terdorong dan termotivasi untuk terus berlatih dan belajar secara aktif. Sehingga memberi sumbangan terhadap kemampuan menulis siswa.

\section{c. Pengertian Paragraf}

Istilah paragraf merupakan hal yang sudah sering didengar, bahkan pernah juga digunakan dalam percakapan maupun praktek. Paragraf merupakan satuan bagian karangan yang digunakan untuk menggungkapkan sebuah gagasan dalam bentuk untaian kalimat. Sejumlah kalimat dalam paragraf tersebut satu sama lain harus saling berhubungan. Tarigan (1981: 11) menyatakan "Paragraf yang merupakan seperangkat kalimat yang tersusun secara logis dan sistematis yang merupakan satu kesatuan ekspresi pikiran yang relevan dan mendukung pikiran pokok yang tersirat dalam keseluruhan karangan”.

Selanjutnya Kosasih (2003: 22) menyatakan "Paragraf merupakan bagian dari karangan (tertulis) atau bagian dari 
tuturan (kalau lisan). Sebuah paragraf ditandai oleh suatu kesatuan gagasan yang lebih tinggi atau lebih luas dari pada kalimat".

Sebuah paragraf mengandung pikiran yang didukung oleh semua kalimat dalam paragraf tersebut. Kalimat-kalimat dalam paragraf haruslah saling bertalian untuk membentuk suatu gagasan yang utuh.

\section{d. Fungsi paragraf}

Tarigan (1981: 12) menyatakan fungsi paragraf yaitu:

1. Penampung fragmen pikiran atau ide pokok.

2. Alat untuk memudahkan pembaca memahami jalan pikiran pengarang.

3. Alat bagi pengarang untuk mengembangkan jalan pikiran secara sistematis.

4. Pedoman bagi pembaca mengikuti dan memahami alur pikiran pengarang.

5. Alat untuk penyampai fragmen pikiran atau ide pokok pengarang kepada pembaca.

6. Sebagai penanda bahwa pikiran baru dimulai.

7. Dalam rangka keseluruhan karangan paragraf dapat berfungsi sebagai pengantar, transisi dan penutup.

\section{e. Pengertian Eksposisi}

Kata eksposisi dari bahasa Inggris Exposition yang berarti "membuka" atau “memulai". Suparno (2008: 5.4) menyatakan, "Eksposisi merupakan karangan yang bertujuan untuk memberitahu, mengupas, menguraikan, atau menerangkan sesuatu. Dalam eksposisi masalah yang dikomunikasikan terutama adalah informasi”. Selanjutnya menurut Keraf (1997: 3) mengatakan "Eksposisi atau paparan adalah suatu bentuk tulisan yang berusaha untuk menerangkan dan menguraikan suatu pokok pikiran yang memperluas pandangan atau pengetahuan seseorang untuk membaca uraian itu". Hal yang dikomunikasikan terutama berupa:

a. Data faktual, misalnya tentang suatu kondisi yang benar-benar terjadi atau bersifat historis.

b. Suatu analisis atau suatu penafsiran yang objektif terhadap seperangkat fakta.

c. Fakta tentang seseorang yang berpegang teguh pada suatu pendirian yang khusus asalkan tujuan utamanya adalah memberikan informasi. 


\section{- Ciri-ciri paragraf Eksposisi}

1. Berusaha menjelaskan tentang sesuatu.

2. Gaya tulisan bersifat informatif.

3. Fakta dipakai sebagai alat konkritasi.

4. Fakta dipakai sebagai alat kontribusi

- Langkah-langkah Penyusunan Eksposisi

Langkah- langkah dalam membuat karangan eksposisi sebagai berikut:

1. Menentukan topik/tema

2. Menetapkan tujuan

3. Mengumpulkan data dari berbagai sumber

4. Menyusun kerangka karangan sesuai dengan topik yang dipilih

\section{Mengembangkan kerangka} menjadi karangan eksposisi

Sebelum memulai mengarang, topik atau tema eksposisi harus sudah ditentukan. Topik itu pikiran, gagasan atau ide yang menjadi pusat dan akan menjiwai seluruh eksposisi. Topik inilah yang akan dikembangkan menjadi karangan. Oleh karena itu, topik tidak boleh terlalu luas, karena akan menjadi panjang sekali.

Tujuan utama karangan eksposisi itu semata-mata untuk membagikan informasi, dan tidak sama sekali untuk mendesak atau memaksa pembaca untuk memerima pandangan atau pendirian pandangan atau pendirian tertentu sebagai suatu yang benar. Sering kali eksposisi itu pendek dan sederhana, misalnya petunjuk bagaimana menggunakan obat kulit. Tidak jarang paparan itu panjang dan sukar, misalnya menguraikan teori atau gagasan baru. Tetapi panjang atau pendek, sukar atau mudah, setiap eksposisi harus dipersiapkan dengan seksama. Agar karangan bertambah jelas, sering disertakan gambar, denah, dan sejenisnya. Sebelum memaparkan sesuatu, seseorang harus memahaminya terlebih dahulu, jika tidak eksposisi menjadi kabur. Gagasan demi gagasan harus disusun secara teratur, sehingga mudah dipahami.

\section{METODE PENELITIAN}

Metode yang digunakan dalam penelitian adalah metode deskriptif yaitu cara atau teknik penelitian yang bersifat memaparkan data berdasarkan fakta yang ada dilapangan. Dalam penelitian ini yang akan dideskripsikan kemampuan menulis paragraf eksposisi.

\section{HASIL DAN PEMBAHASAN}

Dalam melaksanakan penghitungan hasil tulisan siswa dalam menulis paragraf 
berdasarkan teknik klasifikasi, penilaian

didasarkan pada lima aspek yaitu :

1. Gaya tulisan bersifat informatif

2. Penguasaan topik paragraf
3. Fakta dipakai sebagai alat konkritasi

4. Tulisan eksposisi klasifikasi

5. Ejaan

Tabel Penilaian

\begin{tabular}{|c|l|c|}
\hline No & Aspek-aspek Tes & Skor \\
\hline 1 & Gaya tulisan bersifat informative & 20 \\
\hline 2 & Penguasaan topik paragraf & 20 \\
\hline 3 & Fakta dipakai sebagai alat konkritasi & 20 \\
\hline 4 & Tulisan eksposisi klasifikasi & 20 \\
\hline 5 & Ejaan & 20 \\
\hline \multicolumn{2}{r|}{ Jumlah } & 100 \\
\hline
\end{tabular}

Data ini kemudian dianalisis untuk sampai kepada kesimpulan atau pemecahan masalah yang menjadi akhir penelitian. Untuk menganalisis data yang diperoleh penulis menggunakan rumus sebagai berikut:

1. Menentukan skor mentah siswa berdasarkan kesesuaian menulis paragraf eksposisi berdasarkan teknik klasifikasi.

2. Mengubah tes mentah hasil kemampuan menulis paragraf eksposisi berdasarkan teknik klasifikasi dengan menggunakan skala sigma konversi 1-10 untuk menggunakan skala sigma terlebih dahulu harus dicari mean dan standart deviasi dengan rumus yang dikemukakan Arikunto (2009: 246) sebagai berikut:

$$
M=\frac{\sum x}{N}
$$

Keterangan:

$\mathrm{M}=$ Besarnya rata-rata yang dicari $\sum x=$ Jumlah nilai

$\mathrm{N}=$ Jumlah

peserta tes
Keterangan :

$\mathrm{SD}=$ standar deviasi

$x=$ Jumlah nilai

$n=$ Sampel 
3. Menghitung nilai akhir setiap siswa dengan menggunakan skala sigma.

4. Mengkonfirmasikan hasil rata-rata dengan peringkat yang dikemukakan Arikunto (2009: 245) sebagai berikut:

Nilai $8,0-10,0 \quad$ : Baik sekali

Nilai $6,6-7,6$ : Baik

Nilai 5,6-6,5 : Cukup

Nilai 4,0-5,5 : Kurang

Nilai $3,0-3,9 \quad$ : Gagal

5. Membuat persentase kemampuan menulis paragraf eksposisi oleh siswa kelas VII SMP Muhammadiyah 1 Medan.

\section{Menghitung Mean dan Standar}

\section{Deviasi}

a. Menghitung Mean (Rata-rata)

Untuk menghitung nilai rata-rata kemampuan menulis paragraf eksposisi berdasarkan teknik klasifikasi oleh siswa kelas VII SMP Muhammadiyah 1 Medan dengan menggunakan rumus:

$$
\begin{aligned}
& \mathrm{M}=\frac{\sum x}{N} \\
& \mathrm{M}=\frac{2750}{40} \\
& \mathrm{M}=68,75
\end{aligned}
$$

b. Menghitung Standar Deviasi

$$
\begin{aligned}
& \mathrm{SD}=\sqrt{\frac{n \cdot \sum f x^{2}-\left(\sum f x\right)^{2}}{n(n-1)}} \\
& \mathrm{SD}=\sqrt{\frac{40191750-(2750)^{2}}{40(4 \theta-1)}} \\
& \mathrm{SD}=\sqrt{\frac{767000 \theta-7562500}{1560}} \\
& \mathrm{SD}=\sqrt{\frac{107500}{1560}} \\
& \mathrm{SD}=\sqrt{69.91} \\
& \mathrm{SD}=8,36
\end{aligned}
$$

Setelah diketahui mean dan standar deviasi, maka langkah selanjutnya adalah menghitung nilai akhir setiap siswa, dalam hal ini penulis menggunakan rumus skala sigma $1-10$.

\section{Tabel VI}

Konversi Skor ke dalam Nilai Berskala 1-10

\begin{tabular}{|c|c|c|}
\hline Skala Sigma & Skala Sigma 1 -10 & Skala Angka \\
\hline 2,25 & 10 & $\mathrm{M}+2,25(\mathrm{SD})$ \\
1,75 & 9 & $\mathrm{M}+1,75(\mathrm{SD})$ \\
1,25 & 8 & $\mathrm{M}+1,25(\mathrm{SD})$ \\
\hline
\end{tabular}




\begin{tabular}{|l|l|l|}
\hline 0,75 & 7 & $\mathrm{M}+0,75(\mathrm{SD})$ \\
0,25 & 6 & $\mathrm{M}+0,25(\mathrm{SD})$ \\
$-0,25$ & 5 & $\mathrm{M}+-0,25(\mathrm{SD})$ \\
$-0,75$ & 4 & $\mathrm{M}+-0,75(\mathrm{SD})$ \\
$-1,25$ & 3 & $\mathrm{M}+-1,75(\mathrm{SD})$ \\
$-1,75$ & 2 & $\mathrm{M}+-1,75(\mathrm{SD})$ \\
$-2,25$ & 1 & $\mathrm{M}+-2,25(\mathrm{SD})$ \\
\hline
\end{tabular}

Sudjana (1994: 165)

Berdasarkan nilai diperoleh siswa di atas, maka disimpulkan bahwa jawaban pertanyaan penelitian. Kemampuan menulis paragraf eksposisi berdasarkan teknik klasifikasi oleh siswa kelas VII SMP Muhammadiyah 1 Medan berada pada tingkat cukup. Hal ini dapat dilihat dari nilai rata-rata diperoleh siswa yaitu 5,90 dibulatkan menjadi 6 .

Hasil nilai yang diperoleh siswa dinyatakan 2 orang memperoleh nilai 10, 4 orang memperoleh nilai 9,8 orang memperoleh nilai 7,8 orang memperoleh nilai 6,8 orang memperoleh nilai 5,6 orang memperoleh nilai 4,4 orang memperoleh nilai 3.

Berdasarkan hasil penelitian ini, dapat dikatakan kemampuan menulis paragraf eksposisi berdasarkan teknik klasifikasi oleh siswa kelas VII SMP Muhammadiyah 1 Medan perlu diperhatikan labih serius dan bisa ditingkatkan lagi.

\section{E. KESIMPULAN}

Berdasarkan hasil penelitian yang telah dikemukakan dalam penelitian ini, maka kesimpulan yang dapat diambil dari penelitian ini adalah:

1. Dari penelitian di atas, dapat diketahui nilai rata-rata dari kemampuan menulis paragraf eksposisi berdasarkan teknik klasifikasi adalah 5,90 dibulatkan menjadi 6. Apabila dianalisis secara kuantitatif kemampuan menulis paragraf eksposisi berdasarkan teknik klasifikasi berada pada tingkat cukup.

2. Siswa yang mendapat nilai akhir 10 (baik sekali) 5,00\% yaitu 2 orang, yang mendapat nilai akhir 9 ( baik sekali) $10,00 \%$ yaitu 4 orang, yang mendapat nilai akhir 7 (baik) 20,00\% yaitu 8 orang, yang mendapat nilai akhir 6 (cukup) 20,00\% yaitu 8 orang, yang mendapat nilai akhir 5 (kurang) 20\% yaitu 8 orang, yang 
mendapat nilai 4 (kurang) 15,00\% yaitu 6 orang, yang mendapat nilai 3 (gagal) yaitu 4 orang.

\section{DAFTAR PUSTAKA}

Arikunto, Suharsimi. 2006. Prosedur Penelitian Suatu Pendidikan Praktek. Jakarta : Rineka Cipta.

\section{Dasar-dasar}

Evaluasi Pendidikan. Jakarta : Bumi Aksara

Keraf, Gorys. 1997. Eksposisi dan Deskrpsi. Jakarta : Nusa Indah.

Marhijanto, Bambang. 1995. Buku Pintar Bahasa Indonesia untuk SMP. Surabaya : Gita Media Pers

Oemar, Hamalik. 1998. Media Pendidikan. Bandung : Alumni.
Poerdarminta, W. J.S. 1984. Kamus Umum Bahasa Indonesia. Djakarta : Perpustakaan keguruan.

Tarigan, H.G. 1986. Menulis Sebagai Suatu Keterampilan Berbahasa. Bandung : Angkasa.

Tarigan, Djago.1981. Membina Keterampilan Menulis Paragraf. Bandung : Angkasa.

Semiawan, Conny. 1999. Pendekatan Pembelajaran. Jakarta : Gramedia.

Sudjono. 1994. Metode Statistik. Bandung : Tarsito

Soparno, Mohamad Yunus. 2008.

Keterampilan Dasar Menulis. Jakarta :

Universitas Terbuka 